and on superconductivity in thin films, recently as leader of a research group. $\mathrm{He}$ is also at present editor of the Services Electronics Research Laboratory Technical Journal.

\section{Scientific and Technical Personnel in the United States}

Scientific Manpower Bulletin No. 17 (April 1962), issued by the National Science Foundation, summarizes characteristics of scientists reporting to the National Register of Scientific and Technical Personnel, 1960. The median annual salary of United States scientists in 1960 was 9,000 dollars-a 14 per cent increase on the $1956-58$ average. Of the 201,292 reporting, almost half were in private industry or self-employed, 28 per cent were employed by educational institutions, and 16 per cent by Government. Almost 75,000 were employed in research, development or design, nearly 30,000 in teaching and 49,000 in management or administration. The age group 20-29 claimed 18 per cent, 30-39, 40 per cent, and $40-49,24$ per cent. Chemists $(53,000)$, biological sciences $(27,000)$, engineering $(24,000)$, physics $(20,000)$ and the geological sciences $(17,000)$ claimed the largest numbers. Some 25,000 scientists are at present reporting for 1962 .

\section{Overseas Students in Britain}

THe Association of Universities of the British Commonwealth reports 13,385 students ( 1,862 women) enrolled for full-time study or research in United Kingdom universities at the beginning of the academic year 1961-62, compared with 12,410 in 1960-61 and 11,284 in $1959-60$. Of these, 8,086 came from other parts of the Commonwealth, India sending 1,660 and Nigeria 1,124; 297 were studying agriculture and forestry; 3,415 , arts; 165 , dentistry; 2,157, medicine; 1,984, science; 2,316 , social studies; 2,958 , technology; and 93, veterinary science. Of the 5,716 postgraduate students, arts $(1,639)$, medicine (875), science $(1,152)$, social sciences $(879)$ and technology (990) claimed the largest numbers, and most came from India (892), the United States (658), Canada (442), Pakistan (347) and Australia (290). Of the total, 5,850 held an award of some kind and 2,750 were living in college or hall of residence and 10,635 in lodgings or with friends or relatives. There were also 1,981 students enrolled for part-time study or research, of whom 948 came from other parts of the Commonwealth and 956 were postgraduate.

\section{Degree Failures in British Universities}

IN a written answer in the House of Commons on May 16, the Minister of Education, Sir David Eccles, gave the number of students with State Awards who failed their first degree examinations at the Universities of Cambridge and Oxford as 13 out of 1,381 in $1956-57$ and 28 out of 1,516 at other universities; in 1958-59 the corresponding figures are: 14 out of 1,844 and 37 out of 1,331 ; and in 1960-61, 11 out of 2,048 and 40 out of 1,507. For Local Education Authority Awards at all universities the figures are: $1956-57,599$ out of 11,$121 ; 1958-59,697$ out of 13,553 ; and $1960-61,757$ out of 16,022 .

\section{Geophysics and Oceanology in the Indian Ocean and Persian Gulf}

The Survey Ships H.M.S. Owen and H.M.S. Dalrymple returned to the United Kingdom on May 31 after a series of surveys, respectively in the
Indian Ocean and Persian Gulf, as a result of which it has been discovered that the East African Continent may extend underwater almost as far as the Seychelles, nearly 1,000 miles from the existing coastline. Work carried out by H.M.S. Owen has revealed an offshore zone 200 miles wide and extending about 2,000 miles from Madagascar to Socotra. The zone is characterized by a striking absence of gravimetric and magnetic relief, suggesting that the whole zone may be underlaid by a wedge of sedimentary rocks, several miles in thickness. Geologists working on land in East Africa and Madagascar have suspected that the eastward-tilted Continent might continue beneath the deep water of the Indian Ocean, and the findings of H.M.S. Owen this year appear to confirm this. This work has been part of the British contribution to the International Indian Ocean Expedition, jointly sponsored by the International Council of Scientific Unions and by Unesco, and has two objects: the scientific exploration of the marine biology, water circulation and submarine geology of the Indian Ocean; and the encouragment of marine sciences in the countries bordering the Indian Ocean, the rising populations of which may soon compel them to turn to the sea for food. The scientific programme for H.M.S. Owen was planned by a Committee set up by the Royal Society at the invitation of the Hydrographer of the Royal Navy, and its execution was entrusted to the Department of Geophysics, University of Cambridge. H.M.S. Dalrymple has carried scientists from the Imperial College of Science and Technology, and during the season in the Middle East has obtained approximately 5,500 miles of magnetic profiling using a nuclear spin magnetometer. Although recording took place whenever possible, attention was mainly concentrated on the John Murray Ridge in the North Indian Ocean and its extension in the Gulf of Aden. For this special purpose the ship steamed along six tracks specially chosen to cross the Ridge, while all other profiles were obtained during normal working of the ship.

\section{The City Museum, Sheffield}

THE annual report for the year ending March 31, 1961, of the City Museum, Sheffield, records several new displays (Pp. $16+4$ plates. Sheffield: The City Museum, 1962). In the Archæology Gallery, a fouryear task has been brought to completion by the re-arranging of British material dating from the Palæolithic to Mediæval times. When the headquarters of the York and Lancaster Regiment were transferred from Pontefract to Sheffield in 1960, space for part of the extensive regimental museum was allocated at the Weston Park Museum. In the Natural History Galleries a series of new displays, designed to promote interest in bird protection and the conservation of wild-life in general, were introduced. A group of cases illustrating the National Parks of the Peak District, the Highlands of Scotland and East Anglia proved popular.

\section{Dauntney's School Natural History Society}

The report of Dauntney's School Natural History Society covers the period 1959-61 and consists mainly of summaries of the individual field studies carried out by boys and submitted to the Cambridge examiners under their field work scheme (Pp. 44. West Lavington, Near Devizes: Dauntney's School Natural History Society, 1962). Most of their allotted time is devoted to community studies in woodland and fresh water near the school, and to work in the 